\title{
Research on Development and Protection of Minority Traditional Sports
}

\author{
Qiong Wang ${ }^{1}$ \\ ${ }^{1}$ School of Physical Education, Zhaotong University, Zhaotong, Yunnan, 657000 \\ 346591653@163.com
}

KEYWORDS: Traditional Sports; Development and Protection; Minority Sports

\begin{abstract}
And accelerate the development of China's socialist modernization drive of economic globalization, enhance and improve China's cultural soft power has become one of our society faces significant and urgent practical issue. Based on the Perspective of Cultural Soft Power has been involved in all aspects of scientific research of our society, including the Minority Traditional Sports. In this paper, literature research, expert interviews and logical reasoning and other methods of traditional sports of minority status, value, system, content and mode of comprehensive analysis and research to the development of China's traditional sports of minority and cultural soft power to enhance provide a useful reference.
\end{abstract}

\section{Introduction}

Traditional Ethnic Minority Sports refers to the maximum number of sports other than the multi-ethnic nation, is China's traditional national sport an important part of the most unique. It is an important carrier of national culture outward display, but also bear the cultural heritage of the Chinese nation, penetration and fusion of historical responsibility. It is an important resource for the construction of socialist core value system, but also to promote Chinese culture and spiritual strength to move forward. History has proved that China's 55 ethnic minorities in the land of China has created a large number of content-rich, distinctive national sports culture. In today's modern global tide, the entire world of sports as a whole have shown a Western era shrouded sports, the Chinese traditional sport has been marginalized to a certain extent, their survival and development is seriously threatened. National Traditional Sports Culture of "soft power" is experiencing significant weakening, in particular rescue and protection of minority sports have become the focus of attention. Understandably, an important aspect of minority sports culture is the soft power of decay decline, therefore, in the cultural soft power Perspective for Sports Development of national minority to re-examine not only necessary but also feasible, and its significance is mainly reflected in: on the theoretical level, it will help rebuild the system and the system of minority sports system value; on a practical level, contribute to the depth of excavation projects and content development model minority sport in order to achieve strong protection of minorities and Sports Minority rapid revival of traditional sports culture.

\section{The Definition of Minority Traditional Sports}

From a logical point of view, "national sport" should be "national traditional sports" generic concept. Hu Xiaoming the "national sport" and "modern sports" corresponds, he believes that "international popular modern sports, China's national sports should be in place to carry out the Chinese people live, with Chinese traditional characteristics of sport . Baidu Encyclopedia 
collectively describe a "national sport" is: "part of the social sports. All ethnic groups in the long-term social practice accumulation created and developed significantly with the characteristics of folk to fitness, self-defense, recreation as the main purpose of physical exercise activities. Often its long history, moving stories, magnificent color and unique taste of life reflects the customs of various ethnic, cultural characteristics, morality and religion, each nation is a political and cultural life of the particular form of expression. Has a traditional, assembly resistance, resistance festivals, entertainment properties, custom properties, performance and other characteristics. "From a strictly semantic point of view, national sport should correspond to the concept of a 'non-national sport', that is 'foreign sports'.

Foreign sport is coming from outside the Chinese sports, rather than the alien, or that foreign sports. From a strict sense, not necessarily traditional national sport, it also includes modern national sport. As produced in the United Kingdom Bingbing ball, now it has become the most widely used of Jian exhibition 'national sport', and in a sense, it is the modern China's national sport. "As for the 'traditional national sport', some scholars from the time defined as 'traditional national sport', mainly refers to the existence of pre-modern sport was introduced into China sports model, that 1840 years ago, our peoples have been adopted and popular since the sport activities, the sum of expression and social values.

\section{Significance of Traditional Ethnic Sports Development}

Culture is a product of human creativity and it is also part of Chinese traditional sports as the Chinese nation outstanding culture of human culture. National Traditional Sports as an important carrier of an important form of traditional Chinese culture and traditional cultural values, bearing the national cultural heritage, protection, integration and development of hope, it is both important cultural resources to build a socialist core value system, but also to promote Chinese culture continue to develop, expand the international influence of spiritual strength of Chinese culture. "Minority Traditional Sports formed in the long historical development, an important carrier of our national culture, thousands of years crystallization of national culture, has a rich cultural heritage, unique fitness regimen mechanism and rich traditional culture, it is a realistic characterization of Chinese civilization. It is as a tradition of folk culture, arising from the yen will be deeply rooted in the vast land of China, and in the process embodies the tradition of their own value.

\section{The Development and Protection of Traditional Sports}

\section{A. Development and Protection of Cultural Value}

"Cultural heritage, culture refers to as the baton handover procedure similar longitudinal members of a human community in society. This process is due to the existence of environmental constraints and cultural backgrounds and mandatory requirements and models, and ultimately the formation mechanism of cultural heritage so that human culture has stability, integrity, continuity and other features in the historical development of "China's large number of ethnic minorities, national sports culture fine rotten scene, has unearthed many traditional sports. Their presence reflects the cultural diversity, enrich people's daily life, with a great heritage value. Traditional Ethnic Sports Culture both on the history and cultural achievements of inheritance and retention, but also based on the realities of creation and development of social conditions.

The word "culture" comes from the Latin culture. American anthropologist Leslie White, said, "Culture is to make human life means the continuation of the process, which is to provide subsistence, protection, attack and defense, - social adjustment mechanisms need to adapt to the 
outside world and to recuperate, etc. anatomical structure of culture, there are two Takahashi, which is divided into material culture and spiritual culture; there are three levels of that substance that is divided, institutional, spiritual three levels; there are four levels of that substance that is divided, systems, customs, ideas and value. there are six subsystems, said that the physical, social relations, spiritual, artistic, sign language, customs and other generalized culture, focusing on humans and animals in general, the essential difference between human society and nature, focusing on the human Standing out in Natural unique way of life, which covers a very wide range, it is also known as the Great cultural cultural ecology as the Dragon Boat festival as the festival day, from north to south and from east to west, from morning Bian wormwood, iris start, rice dumplings, dragon-boat race. Thus the holidays, do not inform the government, not the command, the people themselves have their own set of procedures holidays, cultural and ecological protection zone to be protected is these thousands of years handed down, into the people things in life.

Cultural anthropologist Kissinger in affirming the social function and meaning of language, said: "Cultural Theory further revision of language and culture raised new questions because if it is the language of discourse on the basis of the concept of codes. the culture is the conceptual basis of social behavior codes, then the language is clearly part of the culture.? "in the era of human language has no words, the traditional sports of the minority heritage mostly take" words and deeds "," mouth Spread the word, "the way, the language of the national traditional Sports culture, heritage plays a very important role. Original literature and art is an intense emotional experience, not just for the pursuit of pure aesthetic pleasure. Through a dignified, solemn and mysterious way the concept of primitive culture outside of it, into an inner spiritual strength affects their spiritual world. Their unique national traditional sports culture is also information obtained during this effect passed quietly. This capability has been maintained up to now, but the role has been different from the way the past, it is not only the communication and interpretation of the traditional sports culture of ethnic minorities, but also bear the guidance of its function and remodeling.

\section{B. Development and Protection of Project Content}

For content project development Minority Traditional Sports should have a global and long-term vision, it is necessary to encourage minority traditional sports to the modern sport "reference", but also the protection of minority traditional sports content items "personality"; it is necessary to fully tap traditional Ethnic Sports content of the "heritage", but also reflect the characteristics of the nation's sports and "innovation." In this way, can we truly traditional minority sports content items with concurrency and get results. Therefore, the current contents of the Minority Traditional Sports with concurrency should be thinking: Lessons and personality of unity, tradition and innovation combined. "Reference" key is to learn from the organization and management methods of modern sport, rather than the introduction of modern athletics content. "Personality" is the requirement in the project development process to be firmly based on the sport habits and activity patterns of the nation, not only can not lose the original features, but also in the project development process as much as possible to highlight these features, otherwise Minority Traditional Sports content with concurrency and will fail. "Inheritance" is a traditional minority sports content "individuality" inherit and carry forward. Inheritance of two-story meanings, one with a traditional minority sports project contents "lost" to organize and conduct a comprehensive project to fully tap its content; the second is to make traditional items in the present minority ethnic groups were popular, especially It is to be carried out in popularity among ethnic minority youths, so they love the nation of sports projects, in order to ensure national traditional sports from generation to generation. "Innovation" means according to the National Sports Project "personality" in the "Reference" on the basis of 
creating a national sport habit reflects this new content, new projects and new ways to make minority onto a traditional project with concurrency new level.

\section{Conclusion}

"Three-dimensional" model of development of traditional sports of minority Construction is mainly based on real development needs and cultural level theory; its main components involved in the spiritual and cultural leader, system security and cultural material and cultural foundation. Together they form a minority traditional sport to enhance the goal of a stable triangle. This mode of operation mechanism includes motivation mechanisms, processes and mechanisms effector mechanism, its main feature is reflected in the relative rationality, three aspects of the relative integrity and dynamic development and so on. Development of this model can provide a useful reference for the further development of Traditional Sports of Minority.

\section{REFERENCE:}

[1] Roland Robertson, Globalization: Social Theory and Global Culture, London:Sage,1992.

[2] Peter Katzenstein (ed), The Culture National Security: Norms and Identity in Worm Pol lties,New York: Columbia University Press,1996.

[3] Pavne Richard J,Politics and Culture in the Developing World: the Impact of Globalization, New York: Longman, 2003.

[4] Tomlinson John, Globalization and culture. Chicago: University of Chicago Press, 1999. 